\title{
Penile Cancer pT2 TNM Finding v7
}

National Cancer Institute

\section{Source}

National Cancer Institute. Penile Cancer pT2 TNM Finding v7. NCI Thesaurus. Code C89173.

Penile cancer with tumor invading corpus spongiosum or cavernosum. (from AJCC 7th Ed.) 